Sign Systems Studies 45(3/4), 2017, 230-248

\title{
Semiotics and culture: The perception of time as a semiotic problem
}

\author{
Boris Uspenskij \\ National Research University Higher School of Economics \\ Moscow, Russia \\ Serebryanicheskij per. 9, kv. 21, Moscow 109028, Russia \\ e-mail: borisusp@gmail.com
}

\begin{abstract}
The perception of time is culturally conditioned which means that in different cultures time may be experienced - perceived, conceptualized and evaluated - in diverse ways. The distinction between past, present and future seems to be a universal phenomenon, but the relations of these categories may be different in different cultural codes. The author defines two models of temporal perception, 'historical' and 'cosmological', analysing the conceptualization of time in each of them. ${ }^{1}$
\end{abstract}

Keywords: semiotics of time; time perception; history; cosmology; past; present; future

And I confess to you, Lord, that I still do not know what time is, and then again I confess to you, Lord, that I do know that I am saying these things in time [...]. But how do I know this, when I do not know what time is? Or by "not knowing" do I perhaps mean simply that I do not know how to express something which is in fact known to me?

Saint Augustine ${ }^{2}$

1 The present paper was prepared for a lecture held in Madrid in 2010 (Congreso de Semiótica de la Cultura, Círculo de Bellas Artes, Madrid). It is based on the second part of the twopart article published by the author under the title "History and semiotics (the perception of time as a semiotic problem)" in Russian in Sign Systems Studies, vols. 22 and 23 (Uspenskij $1988 ; 1989)$. Its present version has not been published before.

2 Confessions, XI, 32. Augustine 1963[ca 400]: 277-278. 
Nous ne nous tenons jamais au temps présent. Nous rappelons le passé; nous anticipons l'avenir comme trop lent à venir, comme pour hâter son cours, ou nous rappelons le passé pour l'arrêter comme trop prompt, si imprudents que nous errons dans des temps qui ne sont point nôtres, et ne pensons point au seul qui nous appartient, et si vains que nous songeons à ceux qui ne sont rien, et échappons sans réflexion le seul qui subsiste.

Pascal $^{3}$

The perception of time is certainly culturally conditioned, which means that in different cultures time may be experienced - perceived, conceptualized and evaluated - in diverse ways. The distinction between past, present and future seems to be a universal phenomenon, but the relations of these categories may be drastically different in different cultural codes.

It should be emphasized that what is past, what is present, and what is future is basically a semiotic problem. Indeed, different types of semiosis may be traced, for example, when we evaluate our present from the perspective of our past or when we do it from the perspective of our future; or when we evaluate our past from the perspective of our present, and so on. Thus, the perception of time appears to be one of the main objects of study of the semiotics of culture.

It seems appropriate to distinguish two possible approaches to time or, rather, two models of temporal perception (two types of consciousness) which may be conventionally defined as 'historical' and 'cosmological'.

The historical approach organizes events relating to our past into a causative series. Events of the past are then viewed consecutively as the result of some other, earlier events. Thus, the historical consciousness always presupposes a reference to some preceding situation - but not the initial one! - which, in its turn, is causally related to yet another, even earlier, preceding situation, and so on.

The cosmological approach, on the other hand, entails the relation of events to a certain primeval state, a first time, which never disappears in the sense that its effects continue to be realized throughout the temporal process. Events which occur in this primeval time form a text which is constantly repeated (reproduced) in the events that follow. This ontologically initial text which in one way or another is related in our consciousness to all following events corresponds to what is customarily understood by the concept of 'myth'.

3 Pensées, no. 47. Pascal 1963[ca 1662]: 506. 
Both ways of conceptualizing the past may determine the perception of the present. In other words, either the historical or the cosmological model of temporal experience worked out from a particular perception of the past may be imposed upon the present.

In the framework of historical consciousness, that is, when the historical model of temporal experience is projected onto the present, events in the present are evaluated from the perspective of the future as it is seen at the given moment. Present events are therefore causally related to the predicted events of the future and are evaluated according to their possible consequences. The significance of the results dictates which events are perceived as significant and, conversely, which events are evaluated as insignificant insofar as they have no foreseeable serious consequences. ${ }^{4}$

Thus, the significance of events is determined by projecting them onto the future, that is, by their perception from the perspective of the anticipated (modelled) future. In other words, in this case the semiotic status of events in the present is conditioned by our assessment of their capacity to affect other, future events (that is, by their causative role).

However, the future is not open to us, it is not our province, and we cannot really know the consequences of the present events. We can only guess what their consequences may be. Our reactions are thus determined by subjective rather than objective factors, not by the essence of things, but by our notions of causal relations. It is only these relations that are actually within our scope.

In the framework of cosmological consciousness, on the other hand, when the cosmological model of temporal experience is projected onto the present, events in the present are perceived as significant in as far as they relate not to a future state, but to an initial state in the past. Present events are seen as the reflection of this primeval past. The present is evaluated in this case not in terms of the future, but in terms of the past. In other words, the present is not viewed as anticipating the future, but it is viewed as a manifestation of an initial state. The semiotic status of present events, thus, depends on their role, not as causes, but as consequences, since they are seen as preordained by events of the primeval time. ${ }^{5}$

If in this process the events of the present are connected to the future, this connection is not a causal connection, but rather a symbolic one. In the cosmological model, causal connections do not link the present and the future, but rather they

4 Cf.: "Nous ne sommes jamais chez nous; nous sommes tousjours au delà; la crainte, le désir, l'espérance nous élancent vers l'avenir, et nous dérobent le sentiment de la considération de ce qui est, pour nous amuser à ce qui sera, voire quand nous ne serons plus" (Montaigne 1962[1580]: 11 , no. I-3). Cf. also Pascal's thought quoted in the beginning.

5 Naturally causal relationships are conceptualized differently from historical and cosmological perspectives: the very concept of causality depends on one's conceptual framework. Cf., in this connection, the opposition between mythological and non-mythological thought, Lotman, Uspenskij 1977. 
connect some primeval state both with the present and with the future. The present and the future are thus connected not directly, but indirectly - by way of this initial, integral and omnipresent state.

So, events of the present are not conceptualized as having generated the future, but they may be viewed as portents of the future. What occurs in the present and what may occur in the future is seen - within the framework of cosmological consciousness as a reflection or symbolic representation of the initial state, actually as signs of that state. The connection between these signs is encoded, so to say, in the world's design. If we know (even if only partially) the connection, then we can predict the future by referring to events of the present, following the guidelines, not of profane experience, but of cosmological notions of how the universe is constructed; that is why all kinds of predictions are so often mentioned in early historical accounts. ${ }^{6}$ Correspondingly, the present reflects the past and portends the future.

Thus, the cosmological perception of the present, which conditions the semiotization of current events, is oriented towards the past, while the historical perception is oriented towards the future. A historical perspective evaluates current events on the basis of our ideas of what the future holds, while a cosmological perspective evaluates them on the basis of our notions of the past. ${ }^{7}$

The historical and cosmological models of time may actually co-exist in our experience. In its relatively pure form the historical model is often realized in scientific notions (for example, in evolutionary biology), while the cosmological

6 It is primarily the coordination with the cosmological order, and not their profane pragmatical value, that makes predictions significant. If predictions are not fulfilled this does not necessarily mean that they are not true. Cf. the words of Quintus, Cicero's brother and an apologist for divination, in Cicero's treatise De divinatione (I, $₫$ LVI, 128): “[...] It is not strange that diviners have a presentiment of things that exist nowhere in the material world: for all things 'are', though, from the standpoint of time, they are not present" (Cicero 1969-1988[ca 43 BC]: XX: 363). Thus things can exist outside of time, and diviners are able to see them independent of their manifestation in time.

Quite analoguosly in the framework of historical consciousness anticipations based on cause-effect relations can be regarded as true and justified even if they are not realized. Guicciardini (1890: 161) wrote: "Although we act on the best advice, yet, so uncertain is the future, the results are often contrary. Still we are not on that account to give ourselves up like beasts a prey to Fortune, but like men to walk by Reason. And he who is truly wise should be better pleased to have been guided by good advice though the result be untoward.... In both cases the knowledge of how the world is organized is actually recognized as far more important than any kind of experience.

7 An important difference, however, is the fact that the historical consciousness assumes that the future does not exist, and therefore accepts the relativity of all knowledge of the future, while the knowledge of the past, so vital for the cosmological consciousness, is regarded as entirely reliable (see below). 
model is realized in religious notions. This applies equally to the individual and collective consciousness. Indeed, man, as a collective or individual personality, may live simultaneously in the projection of the two types of consciousness (or, rather, in the projection of the two types of perception) when the same events are explained as causative laws and as a repetition of earlier states. Thus, one and the same event may simultaneously relate both to the cosmological past and to the historical future. Each orientation entails a different type of semiosis.

It is noteworthy that Christian dogma represents an unusually striking instance of a combined cosmological and historical orientation. Christ is both God and Man, and as the God-Man Christ simultaneously represents a cosmological principle and a historical process. Indeed, Christ is God the Son and God the Word (the hypostases of the Trinity) which "was in the beginning" (John 1:1-3) and is the "beginning of the creation of God" (Rev. 3: 14), "the beginning and the ending" (Rev. 1: 8; 21: 6; 22: 13). According to the Creed, He was born of God the Father "before all ages". And Christ says of Himself: "before Abraham was, I am" (John 8: 58). Remarkably, the tense of the verb in this sentence contradicts the rules of secular grammatical usage, for the form of the present, "am" (Greek eimi), refers to a state that existed earlier than the state that is expressed by the past form "was" (Greek $\gamma \varepsilon v \varepsilon \dot{\varepsilon} \sigma \theta \alpha$ ). The sentence is distinctly ungrammatical because the meaning is above grammar, outside our profane experience. ${ }^{8}$ All this corresponds to the cosmological model of time.

However, Christ's earthly incarnation, from His birth to His resurrection, is related to the historical developments of events and, therefore, also belongs to history. Indeed, He was born "in the days of Herod" (Matt. 2: 1), and the Gospel of St Matthew begins with a genealogy of His paternal ancestors, beginning with Abraham and ending with Joseph (Matt. 1: 1-16; cf. Luke 3: 23-38). This inscription into history, the temporal concreteness of events in the Gospels, is especially stressed in the Creed, exactly where the earthly incarnation of Christ is described: "[He] was crucified for us under Pontius Pilate, and suffered and was buried”. The name of Pontius Pilate, a concrete historical person, refers us to a concrete historical period.

This amalgamation of the cosmological and the historical, of the eternal and the temporal, is of essential importance: it is the manifestation of the divine and human natures of Christ. The cosmological consciousness naturally corresponds to the divine element, while the historical consciousness corresponds to the human element. This dual perspective is characteristic of the orthodox Christian viewpoint developed in the process of theological discussions from the 4 th to the 5 th centuries which treated the incarnation of Christ not as the Divinity's assumption of a material form, but as the real conjunction of the divine and human natures in a single person. The opposite position is professed by the Monophysites (who believe that following the incarnation

8 Cf. in this respect statements against grammar in the Middle Ages. See Uspenskij 1992: 494 ff. 
of God's Son in human form, Christ had a single, divine nature) and by the Nestorians (who believe that Christ is a human with whom the Son of God was temporarily merged). ${ }^{9}$ So dogmatically it turns out to be extremely significant.

Thus, the events of the Gospel are coordinated with the historical process, but may still be experienced as cosmological. One may believe, in particular, that Christ is constantly being born, ${ }^{10}$ that $\mathrm{He}$ is continually being crucified, and so on. In this way the incarnation conditions a dual perception of time in the Christian conception of history, that is, the dual perspective of the historical process - insofar as the historical process corresponds with this culminating event.

This dual perspective seems to be typical of the medieval Christian historiography. Elsewhere I have tried to demonstrate that the notion of Moscow as the Third Rome, developed in Russia at the turn of the 15th and 16th centuries, had both a cosmological and historical foundation in the contemporary consciousness of that epoch (see Uspenskij 2002). Side by side with a sequential unfolding of events which was seen as the realization of certain causative laws, a return to a kind of initial state was postulated. The new role of Muscovy was thus determined both by the immediately preceding events (such as the religious union of Constantinople and Rome in 1439, the Fall of Constantinople in 1453, the overthrow of Tatar rule in Russia in 1480) and by events of the cosmological past (such as the Creation of the World, the Creation of the Church, and the Creation of the first Christian Empire). In other words, events in the present that are current in the given epoch are seen both as the result of some other events which directly preceded in the past and as the manifestation of the cosmological past.

9 Incidentally, all these opinions can be traced in Russian heresies of the 16th-17th centuries. Thus, Russian heretics of the mid-16th century refused to recognize the double nature of Christ (see Koreckij 1963: 334-360). Some heretics (such as Feodosij Kosoj or Matvej Bashkin) would not recognize the divine nature of Christ, while others (such as Vassian Patrikeev) did not recognize the human nature. At the beginning of the 17th century Elder Filaret, a monk of the Troitse-Sergiev Monastery, taught that Christ "was not born of Father before the ages, but was born when the Archangel Gabriel brought the good tidings to the Most Holy Virgin Mary" (Azarjin, Nasedka 1855: 63). We can see here an effort to escape from the coincidence of cosmological and historical concepts of time by locating events of the Gospel on the plane of historical consciousness.

10 As Petrus Lombardus put it, "Christ will be born, is being born, and was born". Correspondingly Meister Eckhart begins his sermon devoted to Christmas with the words: "We celebrate here in temporality with a view to the eternal birth, which God the Father has accomplished and accomplishes unceasingly in eternity, so that this same birth has now been accomplished in time within human nature" (Eckhart 1980: 292). The opposition of cosmological and historical is presented here as the opposition of eternal and temporal: what is being unceasingly accomplished in eternity appears for us in time, that is, on the historical plane. According to Meister Eckhart, time is correlated with the perceiving human being, not with the perceived ontological reality. 
Incidentally, the cosmological model of time perception may be foregrounded, or symbolically resurrected, in the perception of historical events which inaugurate a new era that is assumed to be significant for all mankind or for the fate of a given people. An example from Russian history is the perception of the Petrine period which had a clear mythological character: it was based on the belief of the total rebirth of the country. Peter the Great was seen as the demiurge of a new world, the creator of a new Russia and a new nation. ${ }^{11}$ And later the Russian Revolution was understood in a similar way.

In such cases, historical consciousness yields to cosmological one which compels the historical process to be perceived in mythological categories and terms. Insofar as the cosmological consciousness has religious connotations, it may lead to something like the sacralization of historical figures. Hence both Peter and Lenin became sanctified: both men actually became mythological figures in Russian history.

So far I have been discussing the perception or conceptualization of the past and the present, but what of the perception of the future?

The perception of the future differs substantially from the perception of the present and the past in the sense that the future must be perceived through reflection (premediation) rather than through direct experience. Indeed, the present and the past are part of our individual experience, whereas the future is not given to us and can be perceived only by a speculative process - so to speak, metaphysically. It is natural to model our conception of the future basing on the experience which conditions our perception of the present and the past.

Incidentally, the special status of the future time is reflected in the expression of the grammatical category of tense in many languages. Some languages grammatically distinguish between present, past, and future. Others distinguish past from the non-past but have no grammatical category for future. ${ }^{12}$ We can probably make the generalized supposition that all languages which possess the category of tense distinguish the past, whereas the distinction of future does not appear to be obligatory. Characteristically, in some languages forms of the irreal mood may come to signify the future time.

So the future can be treated differently according to different cultural codes and the conception of the future is actually based on the interpretation of the relation between the present and the past. On the one hand, the present may be perceived from the perspective of the past and understood as that which appeared out of the past,

11 Concerning the perception of Peter I in mythological terms, see Lotman, Uspenskij 1977: 242-243; Lotman, Uspenskij 1984: 62-63; Uspenskij, Živov 1983: 40-45. Cf. also Uspenskij 1977. 12 This is the case, for example, in Church Slavonic and Old Russian. 
which was born of the past. This perception may determine, in its turn, our perception of the future. Insofar as the future has not yet been experienced, we do not know what will actually occur in that time, although we can guess what might happen. However, we do know - we remember - that at one time the present also did not exist, and that our present is the future in relation to the former past (which at that time naturally was the present). By the same token, the present is past in relation to the as yet nonexistent future, that is to say, the present will become the past when the future becomes the present. Thus, the present is the future in the past and the past in the future.

The relation between the past and the present may be transferred to the relation between the present and the future, that is, the future may be conceptualized by analogy with the present. The perception of the future from the perspective of the present is determined then by the perception of the present from the perspective of the past. It is understood as that present which will arise in the future and in relation to which the current present will become the past.

The present, in its turn, may also be conceptualized by analogy with the future, that is, the experience of perceiving the future may, in a secondary way, be applied to the present. Just as one can model (predict) the future, basing this prediction on the present, one can also make a conventional model of the present based on the past, evaluating unrealized possibilities (that is, asking questions such as: What would have happened had the past turned out differently? How can events that might have happened in the past be reflected in the present?). In doing this we deliberately ignore the fact that the present has already been realized in a certain form, and thus we discuss not the actual present, but a present that is potentially possible from the perspective of the past. By taking the past perspective we actually treat the present as the future which does not yet exist (from the viewpoint of that past). Correspondingly we may construct various hypotheses relating to the present.

Mental operations of this sort are typical of our consciousness, a fact that is attested in the widespread grammatical category known as the subjunctive mood. Indeed, the subjunctive mood serves to express potentially possible conditions. It expresses that which actually does not exist but which under certain conditions might have come to existence. These conditions, in turn, are expressed by forms of the conditional mood. Significantly, the conditional mood is usually formed - in various languages - with the help of verbal forms in the past tense which seems to presume some reference to a condition existing in the past: in this past perspective, what is expressed in the conditional mood was still possible. ${ }^{13}$

13 Characteristically, an unrealized condition which could influence the future development of events (the future seen from the past perspective) can be expressed in some languages (e.g. in English or Old Russian) by verb forms in the past perfect tense. 
This possibility of modelling the historical process by turning to the past, thus replaying and reconsidering various situations that might have occurred but did not actually occur, appears to determine the methodological specificity of history as a scholarly discipline. Theoretically speaking, history should be written, so to say, in the subjunctive mood - to put it metaphorically: it should discuss not only what actually has happened, but also what could have happened under certain conditions, that is, it should reveal and revaluate all the options. ${ }^{14}$

Let us return to the conception of future in the historical model of temporal perception. In this model the future appears as time which does not exist. The future is that which will be born of the present, just as the present was born of the past. This time has yet to come. When it does come into being, it will naturally no longer be the future, it will become the present. In this way, the evolutionary, prospective notion of the movement of time, of the historical process imposes itself upon our perception of the future. This notion is naturally written into the historical consciousness. ${ }^{15}$

14 Such an approach presupposes, of course, the introduction of reasonable restrictions, as well as the evaluation of the probability of various options. However, a historian is hardly justified in regarding the actual development of events as the only possible one.

15 St Augustine, who in general acts as a bearer of the historical consciousness, constantly stresses that the future does not exist, but must still come into being. In Confessions (XI, 23-24), he writes, for example: “[...] We often premeditate our future actions, and this premeditation is present [occurs in the present], while the action which we are premeditating, being in the future, does not yet exist. But when we have embarked on it and begun to do what we were premeditating, then that action will exist, because then instead of being in the future, it will be in the present [...] Nothing can be seen which does not exist. And what is already in existence is not future, but present. Therefore, when we speak of seeing the future, what is seen is not the actual future itself (which, being future, does not yet exist), but the causes, or perhaps the signs of that future - causes and signs which are already in existence. And so to those who see them, they are not future, but present, and from them future events are conceived in the mind and predicted. These concepts, again, are already in existence, and by those who make the predictions they are contemplated as being present in the mind... The future, therefore, is not yet, and if it is not yet, it does not exist, and if it does not exist, it is quite impossible for it to be seen. But it can be predicted from the present which is already in existence and which can be seen" (Augustine 1963[ca 400]: 271).

The problem of existence of the future and the past is also discussed in Buddhist literature. Thus the Sautrāntika school denies the reality of the past and the future, admitting only the reality of the present: according to this school, the future was not real before becoming present, and the past was not real after having been present. Meanwhile the Vaibhāsika school maintains that the past and the future "are existent in reality" together with the present. The Vaibhāșikas refer to the words of Buddha who has said: "there 'is' a past and there 'is' a future". The Sautrāntikas object: "If the past and the future exist in the same sense as the present, as realities, why is it, then, that, being existent in the same sense, they are future and past? If the substance of the same element is alone (permanently) existent, what is the reason that 
One may say that the past and the future are recognized as not equal in their existential status, they do not appear to be isomorphic. The past is that which existed in its time, while the future still awaits its existence; the existence of the past is not dependent on the existence of the present, while the existence of the future depends directly on it. We know the past, but can only guess about the future. The past is given to us as a sequentially organized text, whereas only individual (fragmented) moments of the future can be divined. Our knowledge of the past is concrete, while our knowledge of the future is more abstract, and so on. We know that the past was, that the present is, and that the future will be. But 'was' and 'is' actually have a different relationship to each other than 'is' and 'will be': there is no symmetry here. If something was, it is something about which, in the past, it was possible to say: 'it is' (there was a situation when we could say that). If something will be, it is first and foremost something which does not yet exist. If something was, then it is something which is not now, but not something which has no existence at all. If something will $b e$, it is something which is not now and which has no existence as yet. ${ }^{16}$ This is clearly the historical model of temporal perception.

On the other hand, the past may be perceived from the perspective of the present, and this notion may likewise determine the perception of the future. From this perspective, the future is conceptualized as analogous to the past; the perception of the future from the perspective of the present is determined by the perception of the past in that same perspective. Like the past, the future is conceptualized as something that does not exist in the immediately perceptible reality. By the same token, the future does exist in the same way that the past exists. Both are part of some other reality, something that exists but is not accessible to direct sensory perception, for it

it is spoken of as "having not yet appeared" or "gone"?... Thus, it is that the notion of three times will altogether have no real foundation, as long as you don't accept the view that the elements appear into life out of non-existence and return again into non-existence after having been existing". They treat Buddha's words in the sense that the word 'is' virtually refers to the language of description, not to the described universe: "For the word 'is' acts as a particle (which may refer to something existent and to non-existence as well). As e.g. people will say: "there is absence of light" (before it has been kindled), "there is absence of light after (it has been put out)" [...] When Buddha declared that there "is" a past and there "is" a future, he used the word "is" in that sense" (Stcherbatsky 1961: 64-66, 72-73, cf. 36).

16 We are deliberately setting aside the question of the meaning of 'is', whose definition presents obvious difficulties. Disputes regarding the existence of God, for example, generally come down to disputes about the nature of existence rather than the nature of God. In other words, the disagreements are not so much about the word 'God', as about the word 'is', which is quite difficult to define and which admits of many interpretations. Without attempting to define 'is', then, let us point out that 'was' is closer to 'is' in the given temporal context than 'will be. Presumably, the meaning of the word 'is' becomes a component in the meaning of 'was' and is absent in the meaning of 'will be'. 
is located outside our actual experience, outside our vision. The past and the future then become entirely equal in their existential status, they are distinguished only empirically, but not existentially. The difference between them depends entirely on our varying experiences (insofar as we have not experienced the future, but we have already experienced the past), but not on the reality of their own existence. The future is perceived as something which already exists somewhere, but has not reached us yet. We might say that, like the past, the future is given to us as a sequentially organized text, but it is a text which we have not yet read.

This notion of the future is part of the cosmological model of temporal perception. Indeed, in the cosmological consciousness, as we know, all events reflect some primary, initial state (the beginning of time) which is bound equally to the present, future, and past. ${ }^{17}$ They are differentiated not by their existential status, but by their relation to the experience of the perception. Time is seen not as constantly arising, but as existing: it may be conceptualized as something which has been created. The notion of the creation of time is determined by the notion of the creation of the world.

While in the instance examined above - when the historical model of temporal perception was discussed - the perception of the future is based on the idea of evolution, coming-into-being, developing, in this case it is based on the idea of predestination. Just as a text of past events exists, there exists a text of future events, of all that is predestined to come into being. That text may be accessible in varying degrees to seers and clairvoyants who are able to perceive what occurs in another place or another time. The capacity to see into the future may also be acquired during certain rituals which we would regard as magical. This can be illustrated by all kinds of fortune-telling as well as by recourse to oracles. ${ }^{18}$

It is noteworthy that in principle the text of the future may even be accessible to perception, but it is assumed in this case that ordinary people without supernatural powers cannot read it - that is, they are incapable of receiving the information contained in it. Especially characteristic here is the description of the miraculous columns of Constantinople in Robert of Clari's account of the conquest of Constantinople by the crusaders at the beginning of the 13th century. Robert of Clari speaks about the

17 Here the term 'past' means events of the previous time which do not directly relate to the initial time - it is possible to qualify it as the empirical past.

18 Since the historical consciousness correlates the temporal process with the arising of a new state, not with returning to a previous state, time is conceived as irreversible. Otherwise we could both predict our future and reconstruct our past. Cf. Schlegel's definition of the historian as a prophet predicting backwards: "Der Historiker ist ein rückwärts gekehrter Prophet" (Schlegel 1905: 59). The cosmological consciousness does not exclude such an opportunity. Thus, in particular, time is acknowledged to be reversible in Buddhist thought: the aspiring Boddhisattva reverses time's flow, retracing all his previous existences in an inverted order. See Mus 1939; Eliade 1973: 188; Needham 1965: 47, note 3. 
columns of Theodosius the Great in the Forum of Theodosius (the Tauros), erected in 386, and of Arcadius in the Forum of Xerolophos, erected in 403; they were modelled on the column of Trajan in Rome. Both columns were covered with basreliefs illustrating various historical events, both of the past and of the future. The Greeks (the inhabitants of Byzantium) considered that what was depicted there to be prophecies of the Sibyl. These prophecies were thus accessible to perception, but the meaning of the illustrations remained hidden until the corresponding events actually occurred, - and then they would naturally lose the character of prophecies. Robert of Clari writes:

On the outside of these columns there were pictured and written by prophecy all the events and all the conquests which have happened in Constantinople or which were going to happen. But no one could understand the event until it had happened; and when it had happened the people would go there and ponder over it, and then for the first time they would see and understand the event. And even this conquest of the French was written and pictured there [i.e. the invasion by the crusaders about which Robert of Clari narrates - B.U.] and the ships in which they made the assault when the city was taken; and the Greeks were not able to understand it before it had happened, but when it had happened they went to look at these columns and ponder over it, and they found that the letters which were written on the pictured ships said that a people, short haired and with iron swords, would come from the West and conquer Constantinople. (Robert de Clari 1966: 110-111, cf. 1924: 89)

What is telling here is the desire to read the text, even though the reading itself no longer has any practical meaning: the prophesied event has already occurred, but its relation to the text of the prophecy nevertheless turns out to be highly important. The reading of the book of universe has an immanent value, which is basically independent of the pragmatics of daily life. It permits the correlation of events with Providence and thus fills them with meaning. ${ }^{19}$

It seems appropriate to consider in this connection an intellectual experiment suggested by Norbert Wiener who wants us to imagine "an intelligent being whose time should run the other way to our own". According to Wiener,

To such a being, all communication with us would be impossible. Any signal he might send would reach us with a logical stream of consequents from his point of view, antecedents from ours. These antecedents would already be in our

19 As other sources show, however, some citizens of Constantinople attempted to attack these depictions with stones and hammers, assuming that they might thus be able to turn the prophecy against the conquerors. The magic battle against the depictions is seen here as almost more effective than the battle against the conquerors themselves. See Robert de Clari 1966: 110-111; 1924: 89. 
experience, and would have served to us as the natural explanation of his signal, without presupposing an intelligent being to have sent it. If he drew us a square, we should see the remains of his figure as its precursors, and it would seem to be the curious crystallization - always perfectly explainable - of these remains. Its meaning would seem to be as fortuitous as the faces we read into mountains and cliffs. The drawing of the square would appear to us as a catastrophe - sudden indeed, but explainable by natural laws - by which that square would cease to exist. Our counterpart would have exactly similar ideas concerning us. Within any world with which we can communicate, the direction of time is uniform. (Wiener 1961: 34-35) 20

The situation described by Wiener is actually close to the cosmological picture of the world: indeed, the future is seen here as objectively existing, even though it is not accessible to our perception (for us it does not yet exist). ${ }^{21}$ This cosmological picture, however, is described in terms of historical consciousness which presupposes, as we know, the establishment of causal relations between preceding and following states.

If the future state exists, we cannot situate it in the framework of historical consciousness. However, we can describe the cosmological picture of the world in terms of historical consciousness if we imagine two time streams moving in opposite directions - from our present to our future and from our future to our present. The time stream which moves towards us - from our future to our present - is not conceivable in the framework of historical consciousness; but it can be conceived of within the cosmological framework. The switching over to the cosmological model transforms the causal relations into symbolic links: the present is then not seen as a basis for the future, but as its portent. What our vis-à-vis (the observer who is located in our future, whose time flow runs in the opposite direction from ours) sees as movement of historical time (when every new status is born out of one directly preceding it with their relations seen as causal), may be seen by us merely as a symbol of future events, as their herald: otherwise this temporal process would not enter into our conception of time. Thus, in the example under discussion, a square created by our $v i s-\grave{a}$-vis and sent to us from our future, may be perceived by us either as a suggestion of a square, that is, an accidental association without connection to objective reality, or as an omen (harbinger) of a square.

20 Cf. also: "Flammarion avait imaginé autrefois un observateur qui séloignerait de la Terre avec une vitesse plus grande que celle de la lumière; pour lui le temps serait changé de signe. L'histoire serait retournée et Waterloo précéderait Austerlitz. Eh bien, pour cet observateur, les effets et les causes seraient intervertis; l'équilibre instable ne serait plus l'exception; à cause de l'irréversibilité universelle, tout lui semblerait sortir d'une sorte de chaos en équilibre instable; la nature entière lui apparaîtrait comme livrée au hasard" (Poincaré 1914: 72-73).

21 Characteristically, the idea of time flowing backwards is present in Buddhist mythology: see fn 18 above. 
The cosmological model of time naturally gives rise to associations between time and space, or at least such associations are foregrounded in this case. Indeed, to say that the future exists but is not yet known to us is virtually equivalent to saying that it exists somewhere else, that is, in a different place which is inaccessible to us, but whose reality is beyond doubt. And also the past may be seen as located in another place where we have already been (a place which at that time was part of our experience). ${ }^{22}$ In this way, the perception of space is carried over to the perception of time: time is conceptualized in spatial models and spatial categories. ${ }^{23}$ The association of space and time is a widespread, if not universal, phenomenon.

Now we are justified in posing a question: why is it that time is perceived in spatial categories and not vice versa? Why could we not perceive space in temporal categories? Sometimes we do, but, characteristically, this happens only when we discuss linear (one-dimensional) space: thus, for example, distance may be measured in terms of the time which is required to cover it (cf., e.g.: "The distance between Oslo and Bergen is seven hours", etc.).

The experience of perceiving space is certainly simpler and more elementary than the experience of perceiving time. Space is perceived empirically with our senses, whereas time is perceived by cognition. Our sense organs experience and assimilate space, whereas it is our consciousness that must experience and assimilate time. ${ }^{24}$

22 As St Augustine put it in his Confessions (IX, 23), “[...] if the future and the past exist, I want to know where they are” (Augustine 1963[ca 400]: 271).

23 Cf., in this connection, Brihadaranyaka Upanishad (III, 8: 3-4): "She said: "Yajnavalkya, that which is above the sky, which is below the earth, which is between sky and earth, - that which men speak of as past, present and future: on what is that woven, warp and woof?". He said: "Gargi, that which is above the sky, which is below the earth, which is between sky and earth, - that which men speak of as past, present and future: that is woven on space, warp and woof'" (Zaehner 1968: 55-56; cf. Radhakrishnan 1953: 231). In his commentary to this passage, Stcherbatskoj (1903-1909, II: 53, cf. 56) writes: "Brahman is the essence and cause of all that exists. He is the source of space, and time was created from space".

According to Stoics, time measures the movement of the universe, which is understood as movement in space (Diogenes Laertius 1931-1938[ca 240], II: 245; Chrysippus 1964[ca 206 BC]: 164, no. 509). In On the Creation, Philo defines time as "a measured space determined by the world's movement" (Philo 1929-1962 [ca 50], I: 21;) cf. also his The Eternity of the World, 4, 52-54 (Philo 1929-1962 [ca 50]., IX: 186-189, 220-223). Here also space appears as a primary concept in relation to time.

24 For this reason, events of the external and internal worlds occur in time, whereas only objects of the external world are found in space. Indeed, "[...] our judgments concerning time and events in time appear themselves to be "in" time, whereas our judgments concerning space do not appear in any obvious sense to be in space" (Whitrow 1980: 2). Kant (1910-1975, III: 60) 
Man becomes aware of space by moving in space, by changing his position, that is, he correlates his perceptive and kinetic experience in order to make conclusions about space. Those conclusions can be then generalized and extrapolated: the experience of perceiving a concrete space can be extended to space as such.

The perception of time, in contrast, is abstracted from direct sense perceptions since a person cannot change his position in time as he may in space. For this reason, it requires a higher level of abstraction.

The experience of perceiving space is thus gnoseologically primary. Consequently, it may determine the perception of time which may be conceptualized as a kind of

writes in Kritik der reinen Vernuft (I, \$6): “Die Zeit ist die formale Bedingung a priori aller Erscheinungen überhaupt. Der Raum, als die reine Form aller äußeren Anschauung ist als Bedingung a priori bloß auf äußere Erscheinungen eingeschränkt [...] ist die Zeit eine Bedingung a priori von aller Erscheinung überhaupt, und zwar die unmittelbare Bedingung der inneren (unserer Seelen) und eben dadurch mittelbar auch der äußeren Erscheinungen".

The concept of existence (being) seems to be primarily associated with space rather than with time (cf. fn 15 above): in other words, the primary conditions for existence are spatial, rather than temporal. If existence in space may be viewed as something which is a priori clear, then existence in time must be conceptualized. In distinction to space, time presupposes the possibility of changing an object and thus the problem of existence in time comes down to a problem of identification, the acknowledgement of the object in its new state as the same object that existed earlier. In Kritik der reinen Vernuft (I, \$5), Kant (1910-1975, III: 59) wrote in this regard: "daß der Begriff der Veränderung und, mit ihm, der Begriff der Bewegung (als Veränderung des Orts) nur durch Zeitvorstellung möglich ist; daß, wenn diese Vorstellung nicht Anschauung (innere) a priori wäre, kein Begriff, welcher es auch sei, die Möglichkeit einer Veränderung, d.i. einer Verbindung contradictorisch entgegengesetzter Prädicate (z.B. das Sein an einem Orte und das Nichtsein eben desselben Dinges an demselben Orte) in einem und desselben Objecte begreiflich machen könnte. Nur in der Zeit können beide contradictorischentgegengesetzte Bestimmungen in einem Dinge, nämlich nach einander, anzutreffen sein". The Buddhist philosophical tradition, which does not acknowledge existence in time, has another answer to this question: "all being exists in reality only for a single moment, and in the next moment we have an entirely new being" (Stcherbatskoj 1903-1909, II: 89, cf. 72).

Thus, the question of existence in time may be answered in various ways. Our response is determined by our attitude towards the possibility or the impossibility of identifying changing objects or of identifying different existences. Characteristically, the problem of identification does not arise when considering the existence of objects in space (otherwise it becomes the problem of classification). The very procedure of identification implicitly requires the correlation of the objects being identified in time, but not in space. In fact we may recognize two objects as being the same when they are in different times, but normally cannot do this if they are simultaneously in different places. In other words, a single object cannot be in different places at the same time, but it can be in one and the same place at different times. The distinction between space and time is determined here by the fact that the very ability to make identifications belongs to the perceiving subject who perceives space directly and time indirectly. 
space, that is, conceptualized in spatial categories. Characteristically, as Piaget has noticed, a child conceptualizes 'before' and 'after' as spatial rather than temporal categories (see Piaget 1950: 136).

Generally, time and space are conceptualized as correlated phenomena (categories, forms of being). They are isomorphic and they may be likened to each other. Indeed, space is filled with objects, just as time is filled with events; events are in a sense similar to objects, they may be regarded as isomorphic phenomena. Spatial orientation (such as 'right - left') corresponds in a sense to temporal orientation (such as 'before after'), that is, these types of orientation may also be viewed as isomorphic. Thus, space and time may easily be transcoded (translated) into each other.

The essential difference between space and time is manifested in their relation to the perceiving human subject. Indeed, space is passive in relation to the subject, whereas the subject is active in relation to space. Time, on the other hand, is active in relation to the subject, while the subject is passive in relation to time. A person can move through space with relative freedom, shifting from one place to the next. Time, on the contrary, moves in relation to a person, and that person finds himself in one or another time. That is, he finds himself in that time which was earlier perceived as the future and which for him is now the present. ${ }^{25}$ For this reason, time is naturally associated with movement in one single direction.

Since time has direction, it is perceived as one-dimensional. In fact, time moves in relation to a person in a given direction while a person may move in any direction in space. Therefore, time may be contrasted to space as a one-dimensional phenomenon to a three-dimensional phenomenon. On the other hand, time and space supplement each other, insofar as any event of our world is marked both in time and in space, and thus we are compelled to speak of time as a fourth dimension or to speak of 'spacetime' or 'chronotope' as a general category. ${ }^{26}$

25 The activity of man with relation to time as a matter of principle presupposes supernatural powers. In particular, such activity is presumed to be possible in magical beliefs and rituals. Thus, a soothsayer (for example, a shaman) can be transferred to another time, and this enables him to predict the future. One could also refer in this connection to specific Russian incantations protecting against an evil spirit, which express the idea of an inverted time (time turned backwards). In order to get rid of wood-sprites or some other demons (as well as diseases which were also regarded as demons), Russians used to address them with the words: “Come yesterday!” (Ushakov 1896: 159-160; Zelenin 1914-1916: 795, 1244). Here the demon is being explicitly sent to another time (just as we can send somebody to another place) - and, moreover, he is being sent to a time which does not exist anymore, that is, a time which is gone away and will never come back.

26 Cf. the same category in early Chinese philosophy: "[...] the expression which is now used for 'the universe', yü-chou, has essentially the meaning of 'space-time"' (Needham 1965: 1). 
It should be emphasized, however, that the very notion of the one-dimensionality of time is predicated on an association with space, the projection of time onto space, the conceptualization of time in spatial categories. If we could move about in time as we do in space or if space moved in relation to man as time does, then there would be no essential difference between history and geography. ${ }^{27}$

\section{References}

Augustine 1963[ca 400]. The Confessions of St Augustine. (Warner, Rex, trans.) New York: A Mentor Book.

Azar'in, Simon; Nasedka, Ivan 1855[ca 1653]. Kanon prepodobnomu ottsu nashemu Dionisiyu, arhimandritu Sergievy Lavry, Radonezhskomu chudotvortsu, s prisovokupleniem zhitiya ego. (2nd ed.) Moscow: Abramovy. [Азарьин, Симон; Наседка, Иван. Канон преподобному отиу нашему Дионисию, архимандриту Сергиевы Лавры, Радонежскому чудотвориу, с присовокуплением жития его. Изд. 2-е. Москва: Абрамовы.]

Chrysippus 1964[ca 206 BC]. Stoicorum veterum fragmenta, volumen II: Chrysippi fragmenta logica et physica. (Arnim, Ioannes ab, ed.) Stutgardiae: In aedibus B. G. Teubneri.

Cicero 1969-1988[ca 43 BC]. Cicero. (28 vols.) Cambridge: Harvard University Press.

Diogenes Laertius 1931-1938[ca 240]. Lives of Eminent Philosophers. (2 vols.; Hicks, Robert Drew, trans.) Cambridge: Harvard University Press.

Eckhart 1980[ca 1310]. Breakthrough: Meister Eckhart's Creation Spirituality in New Translation. (Fox, Matthew, trans., intr., comm.) New York: Image Books.

Eliade, Mircea 1973 [1951]. Time and eternity in Indian thought. In: Man and Time: Papers from the Eranos Yearbooks. Vol. 3. Princeton: Princeton University Press, 173-200.

Guicciardini, Francesco 1890[1527]. Counsels and Reflections. (Thomson, Ninian Hill, trans.) London: Kegan Paul.

Kant, Immanuel 1910-1975[ca 1804]. Kants gesammelte Schriften. (Bd. 1-28.) Bd. 3: Kritik der reinen Vernuft. Berlin: Walter de Gruyter.

27 When time is perceived as space, when the future and the past are regarded as somewhere else in contrast to the present which is seen as here and now, then the temporal process appears as a kind of journey, a continuous movement from the past to the future by way of the present. The future will always be on the horizon, it is always ahead just as the horizon is always ahead when we move in its direction. To say that we move towards the future is essentially equivalent to saying that the future comes to us. In both cases, we are referring to the movement of time which may be conceptualized as the movement of a person with relation to time (a conceptualization which emerges naturally when time is perceived spatially).

A typical motif in folklore tells of a traveller who inadvertently enters the future. When he returns from his journey he discovers that he has been gone for an entire epoch. That is, he has unexpectedly returned to a time which for his contemporaries is already the past. The journey destroys the natural process of time: in changing his spatial location the person also changes his location in time. This motif is close to the widely attested motif of visiting the other world. 
Koreckij, Vadim Ivanovich 1963. Hristologicheskie spory v Rossii (seredina XVI v.). Voprosy istorii religii i ateizma 11:334-361. [Корецкий, В. И. Христологические споры в России (середина XVI в.). Вопросы истории религии и атеизма.]

Lotman, Juri M.; Uspenskij, Boris A. 1977. Myth - name - culture. In: Lucid, Daniel P. (ed., trans.), Soviet Semiotics: An Anthology. Baltimore: The Johns Hopkins University Press, 233-252.

- 1984. Echoes of the notion "Moscow as the third Rome" in Peter the Great's ideology. In: Lotman, Juri M.; Uspenskij, Boris A., The Semiotics of Russian Culture. (Shukman, Ann, ed.) Ann Arbor: Department of Slavic Languages and Literatures, University of Michigan, 53-67.

Montaigne, Michel de 1962[1580]. Essais. (2 vols.) Paris: Gallimard.

Mus, Paul 1939. La notion de temps réversible dans la mythologie bouddhique. Annuaire de l'École Pratique des Hautes Études: Section des sciences religieuses 51(47): 5-38.

Needham, Joseph 1965. Time and Eastern Man (The Henry Myers Lecture 1964). Glasgow: Royal Anthropological Institute.

Pascal, Blaise 1963[ca 1662]. Euvres complètes. (Gouhier, d'Henri, preface; Lafuma, Louis, comm.) Paris: Seuil.

Philo [of Alexandria] 1929-1962[ca 50]. Philo. (Colson, Francis Henry; Whitaker, George Herbert, trans.; 12 vols.) Cambridge: Harvard University Press.

Piaget, Jean 1950. The Psychology of Intelligence. London: Routledge \& Paul.

Poincaré, Henri 1914. Science et méthode. Paris: Flammarion.

Radhakrishnan, Sarvepalli (ed.) 1953. The Principal Upanišads. London: Allen \& Unwin.

Robert de Clari 1924[ca 1216]. La conquête de Constantinople. (Lauer, Philippe, ed.) Paris: Champion.

- 1966[ca 1216]. The Conquest of Constantinople. (McNeal, Edgar Holmes, trans.) New York: Octagon Books.

Schlegel, Friedrich 1905. Fragmente und Ideen. (Deibel, Franz, ed.) Munich, Leipzig: Piper \& Cie.

Stcherbatskoj, Fedor I. 1903-1909. Teoriya poznaniya i logika po ucheniyu pozdnejshih buddistov. (2 vols.) St. Petersburg: Asta-press. [Щербатской, Ф. И. Теория познания и логика по учению позднейших буддистов, ч. I-II. Санкт-Петербург: Аста-пресс.]

- 1961. The Central Conception of Buddhism and the Meaning of the Word "dharma". (3rd ed.) Calcutta: Susil Gupta.

Ushakov, Dmitrij Nikolaevich 1896. Materialy po narodnym verovaniyam velikorusov. Etnograficheskoe obozrenie 29/30(2/3): 146-204. [Ушаков, Д. Н. Материалы по народным верованиям великорусов. Этнографическое обозрение 29/30(2/3): 146-204.]

Uspenskij, Boris A. 1977. Historia sub specie semioticae. In: Lucid, Daniel P. (ed., trans., intr.), Soviet Semiotics: An Anthology. Baltimore: The John Hopkins University Press, 107-116.

- 1988. Istoriya i semiotika (vospriyatie vremeni kak semioticheskaya problema): Stat'ya pervaya. Sign Systems Studies[Trudy po znakovym sistemam] 22: 66-84. [История и семиотика (восприятие времени как семиотическая проблема): Статья первая. Труды по знаковым системам 22: 66-84.]

- 1989. Istoriya i semiotika (vospriyatie vremeni kak semioticheskaya problema): Stat'ya vtoraya. Sign Systems Studies[Trudy po znakovym sistemam] 23: 18-38. [История и семиотика (восприятие времени как семиотическая проблема): Статья вторая. Труды по знаковым системам 23: 18-38.] 
- 1992. The attitude to grammar and rhetoric in Old Russia of the 16th and 17th centuries. In: Tachiaos, Antōnios-Aimilios N. (ed.), The Legacy of Saints Cyril and Methodius to Kiev and Moscow: Proceedings of the International Congress on the Millenium of the Conversion of Rus' to Christianity (Thessaloniki 26-28 November 1988). Thessaloniki: Hellenic Association for Slavic Studies, 485-497.

- 2002. Vospriyatie istorii v Drevnej Rusi i doktrina "Moskva - tretij Rim". In: Uspenskij, Boris, Etyudy ot russkoj istorii. St. Petersburg: Azbuka, 89-148. [Воспроиятие истории в Древней Руси и доктрина “Москва - Третий Рим”. In: Успенский, Борис, Этюды от русской истории. Санкт-Петербург: Азбука.]

Uspenskij, Boris A.; Živov, Viktor M. 1983. Zur Spezifik des Barock in Rußland (Das Verfahren der Äquivokation in der russischen Poesie des 18. Jahrhunderts). In: Lachmann, Renate (ed.), Slavische Barockliteratur II: Gedenkschrift für Dmitrij Tschižewskij (1894-1977). Munich: Fink, 25-56.

Whitrow, Gerald James 1980. The Natural Philosophy of Time. (2nd ed.) Oxford: Clarendon Press.

Wiener, Norbert 1961. Cybernetics or Control and Communication in the Animal and the Machine. (2nd ed.) London: John Wiley \& Sons.

Zaehner, Robert C. (ed.) 1968. Hindu Scriptures. New York: E. P. Dutton.

Zelenin, Dmitrij Konstantinovich 1914-1916. Opisanie rukopisej Uchenogo arhiva imperatorskogo Russkogo geograficheskogo obschestva. Vols. 1-3. Petrograd: A. V. Orlov. [Зеленин, Дмитрий К. Описание рукописей Ученого архива императорского Русского географического общества. T. 1-3. Петроград: Тип. А. В. Орлова.]

\section{Семиотика и культура: восприятие времени как семиотическая проблема}

Восприятие времени культурно обусловлено - в разных культурах время ощущается, концептуализируется и оценивается по-разному. Различение прошлого, настоящего и будущего является универсальным феноменом, но отношения между этими категориями могут отличаться в разных кодах культуры. Автор определяет две модели восприятия времени - «историческую» и «космологическую» - и анализирует концептуализацию времени в обеих.

\section{Semiootika ja kultuur: aja tajumine kui semiootiline probleem}

Aja tajumine on kultuuriliselt tingitud, mis tähendab, et erinevates kultuurides võidakse aega kogeda - tajuda, kontseptualiseerida ja hinnata - erineval moel. Mineviku, oleviku ja tuleviku eristamine näib olevat universaalne fenomen, kuid nende kategooriate vahelised suhted võivad erinevates kultuurikoodides osutuda erinevateks. Autor defineerib kaks aja tajumise mudelit 'ajaloolise' ja 'kosmoloogilise' - ning analüüsib aja kontseptualiseerimist kummaski neist. 